\author{
Ks. Krzysztof Kościelniak
}

\title{
CHRZEŚCIJANIE W SYRII I LIBANIE. ZMIANY STATYSTYCZNE W XX WIEKU
}

Wydarzenia polityczne na Bliskim Wschodzie w ostatnim stuleciu przyniosły wiele zmian, których nikt nie był w stanie przewidzieć na początku XX wieku. Dogłębne przeobrażenia dotknęły wszystkich dziedzin, a w sposób jaskrawy uwidaczniają się w zakresie statystyk demograficznych.

\section{UŚCIŚLENIA W STEPNE}

Na wstępie pragnę doprecyzować dokładniej zakres geograficzny i chronologiczny niniejszych porównań statystycznych. Odnośnie pierwszego aspektu, przez Syrię i Liban rozumie się ziemie, które po traktacie w San Remo z 1920 roku weszły w strefę francuskich wpływów. Zatem nie będę zajmować się terenami tzw. „Wielkiej Syrii” z czasów państwa Osmanów, w skład której wchodziły tereny od Synaju po niektóre regiony dzisiejszej południowej Turcji ${ }^{1}$ To ważne dookreślenie geograficzne automatycznie idzie $\mathrm{w}$ parze $\mathrm{z}$ uściśleniem chronologicznym: nasze prezentacje rozpocznę od roku 1920, czyli od czasu, kiedy tereny Syrii i Libanu stały się terytoriami mandatowymi pod zarządem Francji².

Powody wykluczenia $\mathrm{z}$ orbity zainteresowań okresu tureckiej dominacji w Syrii i Libanie na początku XX wieku, wynikają nie tylko ze zmian terytorialnych po pierwszej wojnie światowej i nowej sytuacji geopolitycznej zwiazzanej z rywalizacją francusko-brytyjską w regionie. Mianowicie statystyki osmańskie w sposób wyjątkowo nie rzetelny - aby nie powiedzieć wręcz kłamliwie - przed-

${ }^{1}$ Jednak niezależnie od tego doprecyzowania, dla celów porównawczych we wnioskach uwzględnione zostaną spostrzeżenia na temat liczby chrześcijan na terenach Syrii, Libanu, Jordanii, Palestyny i Izraela, które dziś zajmują obszar osmańskiej „Wielkiej Syrii”.

${ }^{2}$ Szerzej zob.: A.H. H a u a n i, Syria and Lebanon. A Political Essay, London 1946 ; P.K. Нгтт, History of Syria. Including Lebanon and Palestine, London 1951; S.H. LoNGRiGG, Syria and Lebanon under French Mandate, London 1958 ; D. ChEvalier, Lubnän, en: Encyclopédie de l'Islam, t. V, Paris 1986, 793. 
stawiały liczby chrześcijan. W tureckich zestawieniach ludności Imperium Osmańskiego, które zebrał i opublikował Karpat ${ }^{3}$ obserwuje się nadmierne pomniejszanie liczby chrześcijan przy równoczesnym zawyżaniu liczby muzułmanów ${ }^{4}$. Np. statystyki osmańskie dotyczące Ormian przynajmniej o milion zaniżały ich liczbę w stosunku do danych francuskich z okresu przed rokiem 1914'5. Wreszcie chrześcijanie w Syrii i Libanie w czasie Pierwszej Wojny Światowej zostali zdziesiątkowani na skutek wszechobecnej nędzy, niedożywienia, epidemii i inwazji szarańczy. Np. tylko w jednym z regionów Libanu w 1918 roku liczba ludności zmniejszyła się aż o 200.000 mieszkańców ${ }^{6}$. Z tych racji okres dominacji tureckiej na Bliskim Wschodzie domaga się specjalnych badań.

\section{MOZAIKA WSPÓLNOT CHRZEŚCIJAŃSKICH W SYRII I LIBANIE}

Pochodzenie wielu wspólnot chrześcijańskich na Bliskim Wschodzie jest bogatym tematem, który można prezentować w ramach wielotomowych publikacji. Najogólniej różnorodność ta wynikała z kontrowersji dogmatycznych, kulturowych i prawnych związanych $\mathrm{z}$ dyscypliną wewnątrzkościelną.

W miejsce szczegółowej prezentacji warto w tym miejscu wyjaśnić zjawisko silnej identyfikacji każdej grupy chrześcijańskiej ze swym Kościołem. Badacze od dawna zastanawiali się, co powodowało na terenie Bliskiego Wschodu tak trwała łączność wewnątrz-wspólnotową podzielonych chrześcijan ze swoimi Kościołami i hierarchia.

Według analiz historyczno-socjologicznych, paradoksalnie u podstaw tego zjawiska leżała muzułmańska koncepcja państwa i religii, która „udzieliła się” również chrześcijanom. Mianowicie po arabskim podboju Syrii, różne Kościoły zostały włączone $w$ społeczeństwo muzułmańskie. Przy czym islam rozwijając ideę ummy, budował więzy religijne, w dużej mierze niszcząc poczucie przynależności narodowej. Dla islamu bowiem religia oznacza głównie więzy socjalne według schematu: kto znajduje się poza religią znajduje się poza społeczeństwem. Ta rygorystycznie teokratyczna koncepcja społeczeństwa muzułmańskiego, spowodowała, że również chrześcijanie wypracowali podobny model identyfikacji, gromadząc się wokół swoich przywódców religijnych. Każdy Kościół wytworzył swą tożsamość i tradycję, którą zazdrośnie strzegł, posiadał swego przywódcę - patriarchę i w ten sposób tworzył swoista "nację". Owe "nacje" - często powiązane

\footnotetext{
${ }^{3}$ Por. K.H. K a r p a t, Ottoman population 1830-1914, London 1985.

${ }^{4}$ Por. M.A. B e $\mathrm{n}$ a $\mathrm{r}$ d, Les populations de la Syrie. Rapport présenté à la séance 25 mars 1919 , Damas 1919, 1 (odtąd skrót PS).

${ }^{5}$ Por.: K.H. Ka r p a t, Ottoman population 1830-1914...; M. L é a rt, La question arménienne à la lumière des documents, Paris 1913, 50-59.

${ }^{6}$ Por. PS, 1.

${ }^{7}$ Por. J. H a dj j a r, L'influence de la société musulmane sur le droit ecclésiastique dans l'Orient
} 
z elementem narodowym - nosiły odpowiednio nazwę maronitów, melkitów, melkitów katolików, jakobitów, syryjskich katolików, chaldejczyków itd. Rzecz jasna obecnie w dobie ekumenizmu, wiele silnie eksponowanych dawniej różnic zaczyna zanikać; mówi się raczej o różnorodności tradycji i kultury w obrębie jednego chrześcijaństwa.

Przed zaprezentowaniem statystyk dotyczących wspólnot chrześcijańskich Bliskiego Wschodu w XX wieku, warto też ogólnie omówić kościoły, objęte niniejszymi badaniami. Mozaikę chrześcijan w Syrii i Libanie tworzą następujące wspólnoty:

Kościoł melkicki prawosławny. Zwolennicy Soboru Chalcedońskiego (451), a więc łączności z całym Kościołem Powszechnym, zostali nazwani przez swych przeciwników monofizyckich jakobitów i Koptów w Egipcie melkitami, tzn. zwolennikami cesarza bizantyjskiego (por. syryjskie malaka, arabskie malik). W czasie Wielkiej Schizmy Wschodniej (1054), kościół melkicki Antiochii zachował łączność z Rzymem. Dopiero od XVI wieku melkici podzielili się na dwie frakcje: prorzymską i powiązaną z Konstantynopolem (a z czasem z Rosja), tych drugich nazywa się właśnie Kościołem melkickim prawosławnym

Kościól melkicki-katelicki. Wśród melkitów wielokrotnie zawsze znajdowali się zwolennicy unii z papieżem, którzy począwszy od XVII wieku wspierani byli przez katolickie zakony misyjne. W 1724 roku w Kościele melkickim ugruntował się podział na dwie hierarchie, melkici-katolicy zachowując swe tradycje uznali władzę papieża ${ }^{9}$, natomiast melkici_prawosławni opowiedzieli się za autokefalią.

Kościół syryjski (jakobici). Kościół ten powstał na skutek opozycji części syryjskich chrześcijan do dogmatu chrystologicznego o dwóch naturach Chrystusa na Soborze Chalcedońskim. Wydaje się, że był to jednak bardziej opór wobec Bizancjum niż realny spór dogmatyczny. Tak czy inaczej Syryjczycy rozwinęli w państwie Bizantyjskim wspólnotę kościelną, której hierarchię zorganizował Jakub Baradeusz ${ }^{10}$.

Arabe, en: Antioche entre Rome, Byzance et la Mecque, vol. I: Relations islamo-chrétiennes, Beyrouth 1988 , s. 171-184; PS, 1; E. M. T y a n, Histoire de l'organisation judicaire en pays d'islam, vol. I-II, Paris 1943; N. E d e l b y, L'orgine jurisdictions confessionnelles en terre d'islam, en: Proche-Orient chrétien 1(1951), s. 192-200; A. F at t a l, Le statut légal des non-musulmans en pays d'islam, Beyrouth 1958; A. D u c e 1 i e r, Le miroir de l'islam, musulmans et chrétiens d'Orient au Moyen Age (VII'XI' s.), Paris 1971.

${ }^{8}$ Por. i szerzej zob. C. K. K o r o l e v s k i j, Histoire des Patriarcats melkites, t. I-II, Roma-Paris 1910; A.-D. va n d e r B ri n ck e n, Die, "nationnes Christianorum Orientalium" (von der Mitte des 12. bis in die zweite Hälfte des 14. Jhs), Köln 1913, s. 76-103; Ch. D i e h 1, G. M a r ç a i s, Le monde oriental de 395 à 1081, Paris 1944.

9 Por. i szerzej zob.: H. Z a y a t, Les grecs melkites en islam, Hantisa 1953; J. N a s r a 11 a h, R. H a d d a d, Histoire du mouvement littéraire dans l'Église Melchite du V' au XX'e siècle, IV/1 Damas 1996; II/2 Paris 1979; III/1 Paris 1983; III/2 Paris 1981; IV/1 Paris 1979; IV/2 Paris 1989.

${ }^{10}$ Por i szerzej zob.: P. Verg he se, The Syrian Orthodox Church in the Middle East, [w:] A. J. A rberry, Religion in the Middle East, t. I; Judaism and Christianity, Cambridge 1969, s. 477-481; N.Pi gulewsk a, Kultura syryjska we wczesnym średniowieczu, Warszawa 1989; M. Gordillo, Compendium Theologiae Orientalis, Roma 1950 ${ }^{3}$, s. 226-247. 
Kościół syryjsko-katolicki. Dobre kontakty z jakobitami nawiąał Rzym podczas krucjat i wtedy to po raz pierwszy nawiązano unię między tymi kościołami. W następnych wiekach na przemian podejmowano i zarzucano unię; ostatecznie od XVII wieku istnieje prężny kościół syryjskich katolików ${ }^{11}$.

Kościół maronicki. Całkowicie dziś zarabizowani maronici wywodzą się z kościoła syryjskiego i pierwotnie zamieszkiwali obszary nad rzeką Orontesem w pobliżu Apamei przy klasztorze św. Maruna w Syrii. Na skutek inwazji muzułmańskiej zmuszeni zostali do opuszczenia swej ojczyzny i osiadli w trudno dostępnych zakątkach gór Libanu. Utworzyli swoją niezależną hierarchię kościelną a w okresie wypraw krzyżowych wszyscy maronici opowiedzieli się za ścisła unią z Kościołem rzymskim. Jest to najstarsza, najbardziej zwarta i lojalna papiestwu grupa wschodnich chrześcijan ${ }^{12}$.

Ormiański Kościół apostolski. Chrześcijaństwo w Armenii rozwijało się od pierwszych wieków po J. Ch. Hierarchia tego Kościoła nie brała udziału w Soborze Chalcedońskim i odrzuciła jego dogmat chrystologiczny. Obecność ormiańskiego Kościoła w różnych krajach Bliskiego i Dalekiego Wschodu związana była z eksodusem Ormian ${ }^{13}$.

Ormiański Kościół katolicki. Ścisłe kontakty części hierarchii Ormiańskiego Kościoła apostolskiego sięgają czasów krucjat i od tego czasu podejmowano kilkakrotnie próby utworzenia trwałej unii. Do pierwszej formalnej unii doszło we Lwowie w XVII wieku, a w Cylicji i Aleppo w roku 1740. Obecnie siedziba patriarchy ormiańskich katolików jest Bejrut ${ }^{14}$.

Kościół asyryjski (nestorianie). Kościół ten był pierwszym, który po odrzuceniu postanowień Soboru Efeskiego (431) oddzielił się od Kościoła Powszechnego. Szybko uniezależnił się całkowicie zadomawiając się głównie w Persji. Na okres średniowiecza przypadła jego największa działalność misyjna na Wscho$\mathrm{dzie}^{15}$.

Kościół chaldejski. Od XIII wieku datuje się pierwsze kontakty Rzymu z Kościołem asyryjskim. Mimo wcześniej podejmowanych prób trwała unia z Ko-

11 Por. i szerzej zob. W. de Vries, Dreihundert Jahre syrische-katholische Hierarchie, „Ostkirchliche Studien” 5(1956), s. 137-157; J. M a d e y, Die Ostkirchen - unsere Nachbarn, Köln 1964; M a r Yus s ef Mou na yer, Die syrische Kirche von Antiochen und itre ökumenische Situation, „Ut omnes unum" 36(1973), s. 66-75.

${ }^{12}$ Szerzej na ten temat zob.: P. D i b, Histoire de l'Église Maronite, Beyrouth 1962; J.-P. Valo$\mathrm{g} \mathrm{n}$ e s, Vie et mort des Chrétiennes d'Orient. Des origines a nos jour, Paris 1995, s. 368-405.

${ }^{13}$ Szerzej na ten temat zob.: M. O r m a n i a n, The Church of Armenia, London 1955; L. A r p e e, Armenian Christianity from the Beginning to our own Time, New York 1946; K. S a rk is s i a n, The Council of Chalcedon and the ArmenianChurch, London 1965.

${ }^{14}$ Szerzej na ten temat zob.: J. M. Te r zi a n, Le patriarcat de Cilicie ef les Arméniens catholiques, Beirouth 1955; G. Petrowicz, La chiesa Armena in Polonia, Roma 1971.

${ }^{15}$ Szerzej na ten temat zob. Y. Y a coub, Babylone chrétienne. Géopolitique de l'Église de Mésopotamie, Paris 1996ł P. R ondot, Les Chrétiens d'Orienti, Paris 1955; J.-M. F i e y, Assyrie chrétienne, t. I-III, Beyrouth 1965-1968; A. J. M a c l e a n, W. H. B r o w ne, The Catholicos of the East and his people, London 1892. 
ściołem katolickim rozpoczęła się w XVII wieku. Z czasem 9/10 asyryjskich chrześcijan przystąpiło do jedności ze Stolicą Apostolską. Obecnie patriarcha chaldejski rezyduje w Bagdadzie ${ }^{16}$.

Łacinnicy. Wszystkie kościoły unickie noszące przydomek „,katolicki” należą do jednego Kościoła katolickiego. Posiadają swe prawa, liturgię, zachowują swe partykularne zwyczaje, równocześnie uznają papieża i dogmatykę katolicka. Łacinnikami na Wschodzie nazywa się katolików, którzy związani są rytem łacińskim (rzymskim) obecnie jak każdemu wiadomo sprawowanym w językach narodowych. Są to bądź osiadli na Bliskim Wschodzie Europejczycy, bądź Arabowie-chrześcijanie, którzy od wieków związali się z duszpasterstwem franciszkanów ${ }^{17}$.

Protestanci. Począwszy od XIX na Bliskim Wschodzie działają różne wspólnoty protestanckie, które były popierane przez Anglię, Prusy i inne kraje protestanckie $^{18}$.

\section{DANE STATYSTYCZNE ODNOŚNIE CHRZEŚCIJAN W SYRII I LIBANIE}

Przed prezentacją danych statystycznych odnośnie do Syrii i Libanu począwszy od 1920 roku, warto ukazać sytuację w roku 1919, ostatnim roku tzw. Wielkiej Syrii. Według badań Bernarda opublikowanych w Les populations de la Syrie. Rapport présenté à la séance 25 mars 1919, którymi byli żywo zainteresowani wkraczający na arenę Bliskiego Wschodu Francuzi, wynika, że na terenie Wielkiej Syrii (powtórzmy: na obszarach od Synaju do dzisiejszej południowej Turcji) - zamieszkiwało ok. trzy i pół miliona mieszkańców. Blisko dwa i pół miliona $z$ tej populacji stanowili muzułmanie, w tym dwa miliony sunnitów, pozostali to Druzowie, szyici, Alewici, Izmaelici i Jezydzi ${ }^{19}$. Żydów było $125.000^{20}$. Natomiast chrześcijanie, w liczbie ok. 950.000 , reprezentowali wtedy $25 \%$ całej populacji. Najliczniejsi byli katolicy wszystkich rytów 605.000 (w tym ok. 20.000 łacinników), na drugim miejscu kościoły prawosławne 330.000 i na końcu grupy protestanckie 15.000. Pośród kościołów unickich w ramach Kościoła katolickiego najliczniejsza grupę stanowili Maronici 380.000 i melkici-katolicy $170.00^{21}$, pozostałe

${ }^{16}$ Por. i szerzej zob.: G. B e $1 \mathrm{tr}$ a mi, La Chiesa caldea nel secolo dell'unione, Roma 1933; J. H a b b i, Signification de l'mion chaldénne de Mar Soulaqa avec Rome en 1553, "L'Orient syrien" 11(1966), s. 99-132; H. d e M a u r o y, Les Assyro-chaldéens dans l'Iran d'aujourd'hui, Paris 1978.

${ }^{17}$ Por. i szerzej zob.: L. L a m m e n s, Acta S. Congregationis de Propaganda Fide pro Terra Sancta, 1721-1847, Quaracchi 1922; zob. też dzieła publikowane w serii: G. G o I u b o v it c h, Bibliotheca BioBibliografica della Terra Santa e dell'Oriente Francescano, Nova Serie, Documenti.

${ }^{18}$ Por. i szerzej zob. J. H a d j j a r, L'Europe et les destinées du Proche-Orient 1815-1848. Unité Arabe - Mission chrétiennes - La question Syro-Palestynienne et Syro-Libanaise, Tournai 1970, s. 5-17; 33$-63 ; 230-261$.

${ }^{19}$ Por. PS, 5.

${ }^{20}$ Por. PS, 7.

${ }^{21}$ Por. PS, 6. 
65.000 katolików przynależało do łacinników $(20.000)^{22}$, syryjskich-katolików (10.000), ormian-katolików i chaldejczyków ${ }^{23}$.

W rodzinie kościołów prawosławnych ponad 70\% stanowili melkici prawosławni (240.000), pozostałe 30\% to jakobici, członkowie Apostolskiego Kościoła Armenii (20.000) i nestorianie.

Paradoksalnie podział Bliskiego Wschodu na wpływy brytyjskie i francuskie stał się datą systematycznego odwrotu chrześcijaństwa z tych terenów. Przyglądnijmy się najpierw temu procesowi w Syrii.

\section{SYRIA}

Dokument władz francuskiego protektoratu na Bliskim Wschodzie Répartition de la population suivant la religion et le sexe z ostatnich lat II Wojny Światowej roku jest jedną z najdokładniejszych statystyk dla Syrii i Libanu. Dane końcowe wyciagane są ze szczegółowych statystyk poszczególnych prowincji. Według tych badań liczba chrześcijan w Syrii w 1944 roku przedstawiała się następująco ${ }^{24}$ :

\begin{tabular}{|c|c|c|c|c|c|c|c|c|c|c|}
\hline Wspólnoty: & 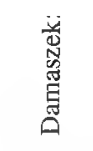 & $\frac{\circ}{\frac{2}{2}}$ & 总 & $\begin{array}{l}\text { 苐 } \\
\text { 蛋 }\end{array}$ & 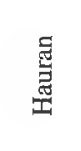 & 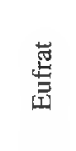 & 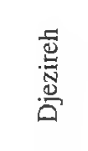 & 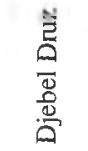 & 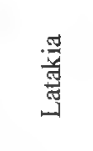 & 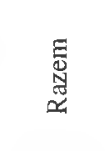 \\
\hline MARONICI & 1.132 & 3.745 & 562 & 39 & 3 & 78 & 58 & 106 & 7.9898 & 13.621 \\
\hline $\begin{array}{l}\text { MELKICI } \\
\text { PRAWOSŁ. }\end{array}$ & 24.197 & 9.611 & 20.391 & 17.586 & 2.907 & 175 & 352 & 4.627 & 59.419 & 139.265 \\
\hline $\begin{array}{l}\text { MELKICI } \\
\text { KATOLICY }\end{array}$ & 20.834 & 12.199 & 3.858 & 376 & 4.981 & 23 & 71 & 2.765 & 2.415 & 47.522 \\
\hline ORMIANIE & 16.988 & 68.651 & 1.534 & 629 & 24 & 1.684 & 8.023 & 359 & 5.288 & 103.180 \\
\hline $\begin{array}{l}\text { ORMIANIE } \\
\text { KATOLICY }\end{array}$ & 2.229 & 9.805 & 1.497 & 49 & 107 & 634 & 1889 & 152 & 710 & 17.072 \\
\hline JAKOBICI & 1.030 & 5.571 & 14.445 & 689 & 59 & 775 & 18.402 & 16 & 7 & 40.994 \\
\hline $\begin{array}{l}\text { SYRYISCY } \\
\text { KATOLICY }\end{array}$ & 3.322 & 6.244 & 3.061 & 264 & - & 726 & 2.945 & - & - & 16.562 \\
\hline ŁACINNICY & 481 & 4.006 & 435 & 13 & - & 26 & 30 & 4 & 1.088 & 6.083 \\
\hline $\begin{array}{l}\text { CHALDEJ- } \\
\text { CZYCY }\end{array}$ & 194 & 2.267 & 23 & 1 & - & 252 & 1.985 & - & 43 & 4.765 \\
\hline NESTORIANIE & - & - & - & - & - & - & 9.215 & - & - & 9.215 \\
\hline PROTESTANCI & 1.618 & 3.129 & 1.758 & 525 & 27 & 29 & 460 & 391 & 3.442 & 11.379 \\
\hline
\end{tabular}

W 1944 roku ludność Syrii wynosiła 2.901.316. Oznacza to, że chrześcijanie stanowili tam 14\% ludności. W porównaniu z rokiem 1919 wydawałoby się, ze nastąpił gwałtowny spadek (wtedy w Wielkiej Syrii było 25\%) chrześcijan, ale należy

\footnotetext{
${ }^{22}$ Por: PS, 6.

${ }^{23}$ Por. PS, 7.

${ }^{24}$ Voir: Conseil Supérieur des intérêts Commune, Service d'Études Économiques et de statistique. Recueil de statistiques de la Syrie et du Liban 1944, t. II, Beyrouth 1946, s. 17.
} 
wziąć pod uwage, że Wielka Syria obejmowała także Liban. W tym samym roku liczba mieszkańców Syrii i Libanu wynosiła 4.027.917 w tym 1.003.668 chrześcijan. Zatem dla Syrii i Libanu statystyka $25 \%$ populacji chrześcijan utrzymała się przez 25 lat od roku 1919 do 1944. Natomiast nie można tego dokładnie powiedzieć o terenach całej tzw. Wielkiej Syrii, czyli Syrii, Libanie, Jordanii i Palestynie. Na tych terenach łącznie zamieszkiwało w 1944 roku ok. 20\% chrześcijan. Związane to było $z$ emigracją chrześcijan, wzmagającym się osadnictwem żydowskim i większym przyrostem naturalnym pośród muzułmanów.

Dane statystyczne zaprezentowane przez N. A. Hornera opublikowane w 1989 roku uchodzą za jedne z najbardziej miarodajnych (dotyczą one stanu z lat 1987-1988). Zestawiając rubryki odnośnie Syrii z licznych przedstawionych tam tabel, uzyskuje się następujący liczbę chrześcijan z poszczególnych kościołów ${ }^{25}$ :

$\begin{array}{lr}\text { Maronici } & 25.000 \\ \text { Melkici prawosławni } & 450.000 \\ \text { Melkici katolicy } & 100.000 \\ \text { Ormianie } & 100.000 \\ \text { Ormianie katolicy } & 22.000 \\ \text { Jakobici } & 80.00 \\ \text { Syryjscy katolicy } & 20.000 \\ \text { Eacinnicy } & 10.000 \\ \text { Chaldejczycy } & 6.000 \\ \text { Nestorianie (Kościół asyryjski) } & 15.000 \\ \text { Protestanci } & 18.000 \\ \text { Razem: } & 846.000\end{array}$

Jeśli te dane o liczbie chrześcijan z lat 1987-1988 zestawić z liczbą mieszkańców Syrii w omawianym okresie, która wynosiła 10.317 .000 (w roku 1984) ${ }^{26}$, wynika z tego, ze chrześcijanie stanowili tam ok. 8,2\%. Wynik tego szacunku jest w dużej mierze zbieżny $z$ danymi na temat liczby chrześcijan w Syrii zamieszczonymi w 1996 roku w Harenberg Kompaktlexikon (podaje się tam 8,9\% chrześcijan w Syrii $)^{27}$. Zatem w ciągu czterdziestu lat liczba chrześcijan w Syrii zmniejszyła się z 14 do $8(8,5) \%$.

\section{LIBAN}

Historycznie Liban pod wieloma względami odbiegał od reszty osmańskiej prowincji „Wielkiej Syrii”. W Górach Libanu zamieszkiwało ponad 60\% chrześcijan świetnie zorganizowanych wokół swego kościoła na czele z patriarchą. Kole-

\footnotetext{
${ }^{25}$ Por. N.A. H or ne r, A Guide to Christian Churches in the Midle East. Present day Christianity in the Midle East and North Africa, Elkhart 1989, s. 96-117.

${ }^{26}$ Liczba mieszkańców Syrii w 1984 roku wynosila 10.317.000. Por. Syria, [w:] The New Encyclopaedia Britannica, t. XI Micropaedia, London $1988^{15}$, s. 468.

${ }^{27}$ Por. Harenberger Kompaktlexikon, t. III, Dortmund 1996, s. 2912.
} 
gium Maronickie w Rzymie przez wieki kształciło duchowieństwo arabskie z Libanu przyczyniając się do szerokich kontaktów Maronitów ze światem zewnętrznym. Pod wieloma względami stanowili oni wyjątkową wspólnotę chrześcijańską w imperium tureckim, np. tylko maronici nie stosowali się do prawa miletu (czyli zwierzchnictwa sułtana nad wspólnotami chrześcijańskimi) które wiązało się z ingerencją władców muzułmańskich na nominacje biskupów i patriarchów. Patriarcha maronicki otrzymywał zatwierdzenie swego urzędu zawsze od samego papie$\dot{z} a^{28}$.

Wracając do danych statystycznych rozpoczniemy od roku 1921, w którym dokonano w Libanie ogólnego oszacowania liczby chrześcijan, które przedstawia się następująco:

Maronici

Melkici prawosławni

Melkici katolicy

Inne kościoły prawosławne i katolickie

Protestanci

Razem:

289.657

Z kolei według bardziej solidnego spisu z roku 1932 liczba chrześcijan w Libanie przedstawiała się następująco:

A) Kościoły katolickie

Maronici

247.000

Melkici katolicy

50.000

Syryjscy katolicy

2.800

Armeńscy katolicy

6.000

Chaldejczycy

600

Razem:

306.400

B) Kościoły prawosławne:

Melkici prawosławni

84.000

Jakobici

2.800

Ormianie

40.000

Nestorianie

200

Razem:

127.000

\footnotetext{
${ }^{28}$ Por. i szerzej na ten temat zob.: Y. E. Ö z v e r e n, La spécificité du Liban durant le dernier siècle de l'Enpire Ottoman, [w:] D. P a n z a c (ed.), Histoir econonique et sociale de l'empire Ottoman et de la Turquie (1326-1960), Paris 1995, s. 677-685; M. J o u p I a i n, La Question du Liban: érude d'histoire diplomatique et de droit international, Paris 1908; S. K h a l a f, Lebanon's Predicament, New York 1987; t e nże, Persistence and Change in Ninteenth Century Lebanon, Beyrouth 1979; N. M u r a d, Notice historique sur l'origine de la nation maronite et ses rapports avec la France, sur la nation druze et sul' les diverses populations du Mont Liban, Paris 1844; J. Th o b i e, Intérêts et impérialisme français dans l'Empire ottoman, Paris 1977.
} 
C) Protestanci różnych kościołów: 9.500

Podliczając te dane wynika, że w roku 1932 wszystkich chrześcijan w Libanie było 442.900 .

W niniejszej prezentacji warto skupić uwagę na statystykach z lat czterdziestych. Według wspomnianego powyżej Répartition de la population suivant la religion et le sexe z 1944 (które dla Libanu przedstawia się nad wyraz szczegółowo bowiem uwzględnia liczbę mężczyzn i kobiet w każdym okręgu) liczba chrześcijan w Libanie rok przed zakończeniem II Wojny Światowej przedstawiała się następująco $^{29}$ (w tabeli m. - mężczyźni; k. - kobiety):

\begin{tabular}{|c|c|c|c|c|c|c|c|}
\hline Wspólnoty & pleć: & Bejrut & Górny Liban & Liban pln. & Liban płd. & Békaa & Razem \\
\hline \multirow[t]{3}{*}{ MARONICI } & $\mathrm{m}$. & 7.065 & 91.041 & 44.118 & 14.125 & 11.010 & 167.359 \\
\hline & k. & 8.339 & 85.207 & 42,358 & 13.867 & 10.716 & 160.487 \\
\hline & razem: & 15.404 & 176.248 & 86.476 & 27.992 & 21.726 & 327.846 \\
\hline \multirow[t]{3}{*}{$\begin{array}{l}\text { MELKICI } \\
\text { PRAWOSŁAWNI }\end{array}$} & $\mathrm{m}$ & 9.773 & 11.567 & 23.834 & 3.458 & 6.595 & 55.227 \\
\hline & k. & 10.302 & 10.806 & 23.688 & 3.453 & 6.407 & 54.656 \\
\hline & razem: & 20.075 & 22.373 & 47.522 & 6.911 & 13.002 & 109.883 \\
\hline \multirow[t]{3}{*}{$\begin{array}{l}\text { MELKICI } \\
\text { KATOLICY }\end{array}$} & $\mathrm{m}$. & 2.802 & 8.252 & 905 & 8.546 & 12.412 & 32.917 \\
\hline & $\mathrm{k}$ & 3.038 & 7.218 & 936 & 8.572 & 11.599 & 31.363 \\
\hline & razem: & 5.840 & 15.470 & 1.841 & 17.118 & 24.011 & 64.280 \\
\hline \multirow[t]{3}{*}{ ORMIANIE } & $\mathrm{m}$. & 17.698 & 7.682 & 524 & 875 & 2.693 & 29.472 \\
\hline & $\mathrm{k}$. & 18.566 & 7.697 & 501 & 820 & 2.693 & 30.277 \\
\hline & razem: & 36.264 & 15.379 & 1.025 & 1.695 & 5.386 & 59.749 \\
\hline \multirow[t]{3}{*}{$\begin{array}{l}\text { ORMIANIE } \\
\text { KATOLICY }\end{array}$} & $\mathrm{m}$. & 2.700 & 1.549 & 93 & 140 & 600 & 5.082 \\
\hline & k. & 2.662 & 1.542 & 101 & 133 & 528 & 4.966 \\
\hline & razem: & 5.362 & 3.091 & 194 & 273 & 1.128 & 10.048 \\
\hline \multirow[t]{3}{*}{ JAKOBICI } & $\mathrm{m}$. & 1.171 & 108 & 49 & 15 & 698 & 2.041 \\
\hline & k. & 899 & $10 I$ & 51 & 7 & 654 & 1.712 \\
\hline & razem: & 2.070 & 209 & 100 & 22 & 1352 & 3.753 \\
\hline
\end{tabular}

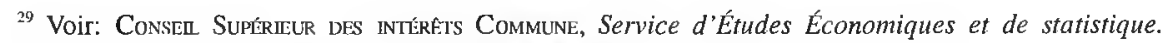
Recueil de statistiques de la Syrie et du Liban 1944, ..... t. II, 25. 


$\begin{array}{llrrrrrr}\text { SYRYJSCY } & \mathrm{m} . & 2.093 & 143 & 90 & 4 & 227 & 2.557 \\ \text { KATOLICY } & \mathrm{k} . & 1.996 & 132 & 79 & 5 & 215 & 2.427 \\ & \text { razem: } & 4.089 & 275 & 169 & 9 & 442 & 4.984 \\ & & & & & & & \\ \text { ŁACINNICY } & \mathrm{m} . & 1.095 & 271 & 28 & 100 & 66 & 1.560 \\ & \mathrm{k} . & 1.096 & 269 & 35 & 79 & 78 & 1.557 \\ & \text { Razem: } & 2.191 & 540 & 63 & 179 & 144 & 3.117 \\ & & & & & & & \\ \text { PROTESTANCI } & \mathrm{m} . & 1.757 & 1.458 & 387 & 913 & 541 & 5.056 \\ & \mathrm{k} . & 2.003 & 1.567 & 363 & 882 & 569 & 5.384 \\ & \text { Razem: } & 3.760 & 3.025 & 750 & 1.795 & 1.110 & 10.440 \\ & & & & & & \text { RAZEM } & \mathbf{5 9 4 . 1 0 0}\end{array}$

Warto dodać, że w 1944 roku Liban posiadał 1.126.601 mieszkańców, w tym 519.244 muzułmanów (sunnici 235.595; szyici 209.338; Druzowie 74.311). Chrześcijanie stanowili 47\% (dokładnie 46,93\%) społeczeństwa.

Statystyki z lat sześćdziesiątych ukazują wzrost demograficzny ludności Bliskiego Wschodu. Dane odnośnie liczby chrześcijan w Libanie z roku 1964 są następujące:

Maronici

Melkici prawosławni

Melkici katolicy

Ormianie

Ormianie katolicy

Syryjscy katolicy

Jakobici

Łacinnicy

Chaldejczycy

Protestanci
698.195

265.009

156.562

91.088

19.716

8.603

8.237

7.801

2.475

18.948

Razem

Dla porównania w tym samym roku Liban liczył 2.366 .386 mieszkańców. Muzułmanów było 1.066.518 (sunnici 479.499; szyici 457.992; Druzowie 130.232), Żydów 7.837 a wyznawców innych religii 13.192 . Zatem liczba libańskich chrześcijan w 1964 wynosiła 54\% i była wyższa o 7\% w stosunku do roku 1944.

Warto baczniej przyglądnąc się zmianom Statystycznym liczby maronitów, którzy od średniowiecza stanowią najliczniejszy Kościół w Libanie. Poniższe zestawienie ukazuje je dla okresu od roku 1925 do 2000: 
rok:

1925

1932

1956

1964

1982

2000 liczba:

178.257

226.378

423.708

698.195

914.635

(ok.) 1.143.294 procent:

$29.81 \%$

$28.82 \%$

$30.03 \%$

$29.5 \%$

$29.27 \%$

$29.07 \%$

Można zaobserwować, że procentowy udział maronitów w Libanie od roku 1925 do 2000 jest niemal niezmienny - cały czas ok. 30\%. Jednak szacunkowy procent maronitów na rok 2000 obliczony na podstawie prognoz z końca lat osiemdziesiatych jest nieprawdziwy; po roku 1996 maronici w Libanie stanowia niewiele ponad $20 \%{ }^{30}$. Oczywiście liczba maronitów wzrosła ponad wspomniane $30 \%$ lecz owa „nadwyżka" wyemigrowała na skutek wojny lub trudnej sytuacji gospodarczej na Bliskim Wschodzie. Dlatego maronici - podobnie jak chrześcijanie wszystkich innych Kościołów orientalnych - tworzą liczne wspólnoty w Ameryce i Europie.

$\mathrm{Na}$ koniec prezentacji chrześcijaństwa w Libanie, przedstawia się statystyki porównawcze z 1932 i 1988 roku:

A) Kościoły katolickie:

Maronici

Melkici katolicy

Syryjscy katolicy

Ormianie katolicy

Chaldejczycy

Łacinnicy

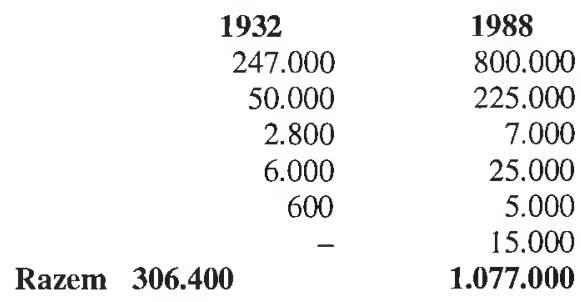

B) Kościoły prawosławne:

Melkici prawosławni

Jakobici

Ormianie

Nestorianie

1932

1988

84.000

300.000

2.800

20.000

40.000

170.000

200

15.000

Razem

127.000

505.000

C) Protestanci:

1932

1988

9.500

25.000

Razem wszyscy chrześcijanie w Libanie:

442.900

1.607 .000

${ }^{30}$ Por. Harenberger Kompaktlexikon, t. II, Dortmund 1996, 1786. 
Obserwując dynamikę wzrostu chrześcijan w Libanie w okresie 1932-1988 należy stwierdzić, że zgodnie z danymi największy rozwój obserwuje się wśród chrześcijan rytu łacińskiego (którzy w latach trzydziestych XX wieku byli marginalną mniejszością w Libanie), wśród nestorian (wzrost 75 razy z 200 do 15.000 ) i wśród chaldejczyków (ponad 8 razy z 600 do 5000). Rozwój tych wspólnot był spowodowany głównie emigracją. Jednak dla tych wspólnot poprzestanie jedynie na analizie procentowej jest mylące i błędne. Bowiem dynamiczny rozwój tych Kościołów rozpoczął się od dalece marginalnych wspólnot w okresie międzywojennym. W konsekwencji owe 35.000 chrześcijan z tych trzech kościołów: łacińskiego, chaldejskiego i asyryjskiego nie zmienia w znaczący sposób współczesnego obrazu religijnego Libanu. Bardziej istotne jest to, że wszystkie inne - tradycyjnie znaczące w Libanie - wspólnoty chrześcijańskie powiększyły się 3-4 razy.

Odnośnie obecności chrześcijan w Libanie w roku 1988, należy stwierdzić, że podawana ich liczba $1.607 .000 \mathrm{w}$ populacji kraju liczącym wówczas ok. 2.700.000 mieszkańców wydaje się imponująca ${ }^{31}$, sięga bowiem ponad $59,5 \%$. W historii najnowszej Libanu był to najwyższy wskaźnik populacji chrześcijańskiej w tym kraju. Niestety na skutek wydarzeń związanych z długotrwałą i krwawą wojną, liczba chrześcijan w Libanie uległa drastycznemu zmniejszeniu; stanowią oni obecnie $40 \%$ społeczeństwa ${ }^{32}$.

W naszych badaniach statystycznych wyszliśmy od stwierdzenia, że w 1919 roku chrześcijanie naterenach od Synaju do Południowej Turcji, czyli dzisiaj na obszarze Izraela, Palestyny, Jordani, Syrii i Libanu stanowili 25\%. Dwadzieścia lat później w tym regionie było ich ok $20 \%$, chociaż w Syrii i Libanie stanowili oni nadal $25 \%$ populacji. Proces zmniejszania się liczby chrześcijan na Bliskim Wschodzie zatrzymał się jedynie w latach 1944-1988 na terenach Libanu, gdzie z $47 \%$ liczba chrześcijan wzrosła do $59,5 \%$ populacji. Natomiast na terenie Syrii następował ciąły spadek procentowy chrześcijan z 14\% w 1944 do 8,2\% w 1988 roku. Podobny proces miał miejsce w społeczeństwach Jordanii, Palestyny i Izraela. Wzrost liczby chrześcijan w Libanie w okresie 1944-1988 nie był jednak aż tak wielki, aby przynajmniej zatrzymać tendencje spadkowe w globalnej statystyce populacji chrześcijan na terenach dawnej „Wielkiej Syrii”; na tych terenach w latach osiemdziesiatych było już ich mniej niż 15\%. Katastrofalny wręcz spadek liczby chrześcijan w omawianym regionie nastąpił po wojnie w Libanie i eskalacji napięć pomiędzy Palestyńczykami i państwem Izrael. W drugiej połowie lat dzie-

${ }^{31}$ Liban w 1985 roku posiadał 2.668.000 mieszkańców. Por. The New Encyclopaedia Britannica, t. VII Micropaedia, London $1988^{15}$, s. 226.

${ }^{32}$ Por. Harenberger Kompaktlexikon, t. II, Dortmund 1996, s. 1786. 
więćdziesiątych XX wieku chrześcijanie stanowili tylko $40 \%$ mieszkańców w Libanie, ok. 8,5 \% w Syrii, co w przeliczeniu na całość populacji tych krajów daje 14,7\% (przypominając po raz kolejny, w 1944 roku w Syrii i Libanie było 25\% chrześcijan!). Pod koniec lat dziewięćdziesiątych nastąpił równieź poważny spadek liczby chrześcijan do niecałych $5 \%$ w Jordanii, i poniżej $2 \%$ w Izraelu i Palestynie. Obecnie na ok. 29.100.000 obywateli Libanu, Syrii, Jordanii, Izraela i Palestyny chrześcijanie stanowią ok. 2.890 .000 co stanowi 9,93\%. Zatem procent chrześcijan w tym regionie spadł z 25\% w roku 1919 poniżej 10\% w roku 2000 .

Głównymi powodami zmniejszania się ludności chrześcijańskiej na Bliskim Wschodzie są wojny i niestabilna sytuacja polityczno-gospodarcza, które napędzają emigrację. Ponadto obserwuje się niższy przyrost naturalny wśród chrześcijan w porównaniu z muzułmanami. Jednak niewątpliwie emigracja chrześcijan jest zjawiskiem spędzającym sen z powiek hierarchii Kościołów orientalnych. Przybrała ona charakter ciagły i progresywny. W przekonaniu większości chrześcijan wschodnich, właśnie wspólnoty kościelne płacą najwyższą cenę za wszystkie konflikty dotykające ostatnio ten region. Odwołując się do ostatnich wydarzeń, szacuje się, że na skutek wojny w Iraku, kraj ten opuściło ok. 80.000 chrześcijan spośród pół milionowej wspólnoty Kościoła chaldejskiego. 


\section{Résumé}

Dans nos recherches statistiques, nous sommes partis d'une constatation, qu'en 1919 les chrétiens en Grande Syrie (c'est à dire dans les territoires, qui embrassent aujourd'hui Israel, Palestine, Jordanie, Syrie et Liban) constituaient $25 \%$ de la population. Après vingt ans il y avait dans cet region $20 \%$ des chretiens, mais ensemble en Syrie et au Liban ils faisaient $25 \%$ de la population. Le procès de la diminution du nombre des chrétiens au Proche Orient s'arretait seulement au Liban dans la période 1944-1988, où le nombre chrétiens augmentait de $47 \%$ á $59,5 \%$. Par contre en Syrie même suivait la diminution systematique du pourcentage des chrétiens de 14\% en 1944 l'anné á environs 8,5\% en 1988 l'anné. Le procès semblable avait lieu dans les societés d'Israel, Jordanie, Syrie et Liban. L'augmentation du nombre des chrétiens au Liban dans la périod 1944-1988 n'était pas tellement grand pour arrêter les tendences diminuées dans la statistique totale pour les territoires de l'ancienne Grande Syrie; dans les années quatre-vingtième ils y réprésentaient moins que $15 \%$.

La diminution catastrophale du nombre des chrétiens dans cet région a commencé avec la guerre au Liban et avec l'agrondissement du conflict parmis les Palestiniens et l'état Israel. Dans la deuxième moitié les années quatre-vingt-dixième du $\mathrm{XX}^{\mathrm{e}}$ siècle au Liban il y avait seulement $40 \%$ des chrétiens et environs $8,5 \%$ en Syrie, ce qui constitue $14,7 \%$ de la population de Syrie et Liban ensemble (il faut rappeler qu'encore en 1944 dans ces deux pays il y avait $25 \%$ des chrétiens!). Á la fin dee années quatre-vingt-dixième le nombre des chrétiens se deminuaient aussi en Jordanie (moins que 5\%), en Israel et Palestine (moins que 2\%). Actuelement pour environ 29.100.000 citoyens d' Israël, Palestine, Jordanie, Syrie et Liban il y a 2.890 .000 chrétiens, ce qui nous donne $9,93 \%$. Alors le pourcentage des chrétiens dans ce région a diminué de $25 \%$ en 1919 à moins de $10 \%$ en 2000 . 